\title{
Serine/Threonine-Protein Phosphatase 2A 65 kDa Regulatory Subunit A Beta Isoform
}

National Cancer Institute

\section{Source}

National Cancer Institute. Serine/Threonine-Protein Phosphatase 2A 65 kDa Regulatory

Subunit A Beta Isoform. NCI Thesaurus. Code C34084.

Serine/threonine-protein phosphatase $2 \mathrm{~A} 65 \mathrm{kDa}$ regulatory subunit $\mathrm{A}$ beta isoform (601 aa, $\sim 66 \mathrm{kDa}$ ) is encoded by the human PPP2R1B gene. This protein is involved in the regulation of protein phosphatase $2 \mathrm{~A}$ activity. 